\title{
WOJCIECH PRAŻUCH
}

DOI : $10.14746 /$ rie.2015.9.33

Uniwersytet Pedagogiczny im. Komisji Edukacji Narodowej w Krakowie

\section{Postawy elit politycznych Europy Środkowej wobec integracji z UE w okresie przedakcesyjnym*}

\section{Wprowadzenic}

Jednym z przejawów procesu „europeizacji” społeczeństw krajów EŚ było organizowanie się sceny politycznej w latach 90. XX w. (Roskin, 1993, s. 47-62). W większości z nich obserwowano w pierwszej połowie dekady typowe dla ,neodemokracji”" zjawisko polegające na rozłamach w najsilniejszych formacjach (Antoszewski, Herbut, 1998, s. 47-62). Fragmentacja sceny politycznej, określana mianem ,syndromu Weimarskiego", była w Europie Środkowej zjawiskiem powszechnym. Jej efektem była szybka wymiana władzy pomiędzy antykomunistyczną prawicą a powracającą na scenę lewicą, co zakończyło w Polsce i na Węgrzech okres tzw. „naiwnego postkomunizmu" (Ramonet, 1993).

W połowie lat 90., wraz z kolejnymi alternacjami politycznymi, zaczą się proces odwrotny: poszukiwania sojuszy i większości parlamentarnej oraz łączenia się partii (Potel, 1996, s. 23), a także wyścigu o międzynarodowe uznanie ze strony międzynarodówek lub najbliższych pod względem programowym partii Europy Zachodniej (Waele de, 2001, s. 9). Duże partie polityczne EŚ spodziewały się licznych korzyści z faktu przystąpienia do struktur międzynarodowych. Oprócz pomocy organizacyjnej czy finansowej, chodziło też o ideowe samookreślenie się wobec doktrynalnych tekstów międzynarodowych i uznanie wyłączności danej partii na reprezentowanie określonego nurtu politycznego.

We wszystkich państwach regionu aktywne były też partie o poglądach skrajnie prawicowych. W Czechach, Słowacji i na Wegrzech ta strona sceny politycznej zdominowana została przez jedno ugrupowanie - partię lub koalicję (w Czechach Stowarzyszenie na Rzecz Republiki - Republikańska Partia Czechosłowacji - SPR-RSČl; na Słowacji Słowacką Partię Narodową-SNS² ; na Węgrzech Wegierską Partię Sprawiedliwości i Życia - MIEP ${ }^{3}$ ). W Polsce próby jednoczenia skrajnej prawicy nie przyniosły

\footnotetext{
Badania zostały sfinansowane m.in. ze środków Narodowego Centrum Nauki przyznanych na podstawie decyzji numer DEC-2013/08/M/HS3/00395.

${ }_{1}$ Sdruteni pro republiku - Republikánská strana Ceskoslovenska.

2 Slovenská národná strana.

3 Magyar Igazság és Elet Pártja, SPR-RSCz zdobyla w wyborach 1992 r. 6,5\% głosów, w 1996 r. 8\%. SNS uzyskała w 1992 r. 7,9\% glosów, w 1994 r. 5,4\%, a w 1998 r. MIEP uzyskala 14 mandatów w 386 osobowym Zgromadzeniu Krajowym. Na czeskiej scenie politycznej nowym zjawiskiem było powstanie w marcu $2001 \mathrm{r}$. Bloku Narodowo-Socjalistycznego, grupującego pozaparlamentarne sily skrajnej prawicy, w tym członków rozwiązanych przez MSW Sojuszu Narodowego i Patriotycznej Partii Republikańskiej.
} 
efektu. Za wyjątkiem Słowacji, ugrupowania otwarcie antyeuropejskie i nacjonalistyczne z EŚW nie uzyskały wpływu na politykę państwa (Wojciechowski, 2000, s. 144). Zajmowały pozycję marginalną, jak czescy komuniści czy Węgierska MIÉP Istvana Csurki. Partie reprezentujące tendencje autorytarne, skrajne i klerykalne, nie weszly też w żadne związki z zachodnimi strukturami partyjnymi, bo orientacje te nie zorganizowały się w struktury ponadnarodowe.

Tabela 1

Glówne sily polityczne państw Grupy Wyszehradzkiej a wielkie nurty ideologiczne

\begin{tabular}{|l|l|l|l|l||}
\hline \multicolumn{1}{|c|}{ Czechy } & \multicolumn{1}{c|}{ Polska } & \multicolumn{1}{c|}{ Slowacja } & \multicolumn{1}{c|}{ Węgry } \\
\hline Lewica, socjaldemokracja & CSSD & SLD, UP & SDL & MSzP \\
\hline Agraryści & & PSL & FKgP \\
\hline $\begin{array}{l}\text { Centroprawica chrześci- } \\
\text { jańsko-narodowa }\end{array}$ & KDU-ČSL & $\begin{array}{l}\text { AWS, ROP, ZChN, } \\
\text { BBWR, PO, PiS }\end{array}$ & SDKU, KDH, SOP & MDF, KDNP \\
\hline Liberałowie & ODS, ODA, US & KLD, UW & UD, SDK & $\begin{array}{l}\text { SzDSz, } \\
\text { FIDESz-MPP }\end{array}$ \\
\hline Skrajna lewica & KSČ̃ & ZKP & MP \\
\hline Skrajna prawica & SPR-RSC & UPR, SND, LPR & SNS & MIÉP \\
\hline
\end{tabular}

Źródło: Opracowanie własne.

Z punktu widzenia niniejszej analizy, istotne znaczenie ma fakt, że europejskie afiliacje wzmacniały proeuropejskie postawy w partiach Europy Środkowej (Seiler, 2001, s. 7). Można to zaobserwować na przykładzie formacji postkomunistycznych, przekształconych w socjaldemokratyczne, $\mathrm{z}$ którymi regularne stosunki utrzymywały niemiecka SPD i francuska Parti socialiste.

Wpływ poszczególnych partii na kształt polityki zagranicznej w państwach EŚW był proporcjonalny do ich uczestnictwa we władzy. W pierwszej połowie lat 90., integracja ze WE/UE, uznawana była początkowo za zagadnienie związane wyłącznie z polityką zagraniczną, co powodowało wolniejsze zróżnicowanie opinii w partiach, godzących się na konsensus w tej dziedzinie. Konflikt wokół tematu integracji bywał też często ograniczany na zasadzie rodzaju autocenzury, z obawy przed marginalizacją polityczną. Nowe, reformatorskie partie polityczne rozwijały temat otwarcia na Europe i przyjęcia wartości zachodnich. Również siły postkomunistyczne szybko przechodziły na proeuropejskie pozycje, a formacje liberalne i chadeckie $z$ integracji europejskiej uczyniły element politycznej legitymizacji.

W latach 90. XX w., wszystkie większe partie reprezentowane w parlamentach Polski, Czech, Węgier, Słowacji i Słowenii były przychylnie nastawione do przystapienia do UE. Konkretne przedmioty sporu pojawiły się w krajach kandydujących z chwilą rozpoczęcia negocjacji członkowskich. Po okresie romantycznego podejścia opartego o szeroki, lecz powierzchowny konsensus, wchodzenie w szczegóły integracji oznaczało początek różnicowania się politycznej sceny na tym tle (Rzepkowski, 1998, s. 16-17), a kwestia integracji stawała się elementem polityki wewnętrznej. Przykładowo, debata na temat regionalizacji czy decentralizacji wymagała od partii Europy Środkowej przyjęcia określonego stanowiska. Świadczy o tym postawa czeskiej ODS 
przychylna Europie suwerennych państw, czy też, odwrotnie, skłonność węgierskich liberałów do opowiedzenia się raczej za Europą regionów. Sprawdziła się też prognoza mówiąca o tym, że wraz ze zbliżaniem się decydujących rozstrzygnięć, w coraz bardziej spolaryzowanych społeczeństwach rosnąc będzie popularność partii eurosceptycznych i antyeuropejskich. Na antyeuropejskich lękach niektórych kategorii społeczno-zawodowych korzystały formacje skrajne i populistyczne takie jak partie I. Csurki na Węgrzech, A. Leppera w Polsce czy V. Tudora w Rumunii. W momencie przejścia do fazy negocjacji, powszechne stały się też w krajach regionu polemiki pomiędzy rządem, a opozycją parlamentarną (niezależnie od aktualnej konfiguracji) w kwestii stanu przygotowania kraju i strategii negocjacji. Co warte podkreślenia, badania sondażowe dowodziły, że preferencje wyborcze mają kluczowe znaczenie dla krystalizowania się postaw wobec integracji z UE. Wynikało z tego, że partie polityczne mogą wywrzeć decydujący wpływ na wyniki referendum.

\section{Główni oponenci polityczni czeskiej sceny politycznej}

Analiza postaw partyjnych wobec integracji z UE w poszczególnych krajach pozwala wychwycić obok ogólnych tendencji pewne cechy szczególne. W Czechach, z wyjątkiem lewicy komunistycznej, reprezentującej 10\% wyborców i republikanów Miroslava Sladka nie było w latach 90 . XX wieku poważnej siły otwarcie przeciwstawiającej się integracji z UE. Wszystkie ugrupowania demokratyczne, zalążki przyszłych partii politycznych, proklamowały po wydarzeniach z listopada 1989 r. powrót do Europy, podkreślając przynależność Czechosłowacji do cywilizacji Europy zachodniej. Jak podkreśla Vlasta Kubišová, w okresie pierwszych wyborów, wiosną 1990 r., dyskurs wszystkich ruchów politycznych był bardzo do siebie zbliżony. Wszystkie wspominały w swych programach o WE, lecz była to wzmianka ogólnikowa, czyniąca ze Wspólnoty symbol i odległy cel (Kubišová, 2001, s. 86-91). Po podpisaniu układu stowarzyszeniowego, przez kraj przetoczyła się kampania wyborcza prowadząca do polaryzacji wokół przyszłego członkostwa w UE, ale integracja europejska długo nie stanowiła w Czechach przedmiotu pogłębionej debaty, a czescy deputowani nie czuli się specjalnie zaangażowani w sprawy europejskie (Reschova, 1997). W miarę zbliżania się rozstrzygnięć w negocjacjach, deputowani do Izby Niższej parlamentu przestawali postrzegać sprawy europejskie wyłącznie jako element polityki zagranicznej, a ich poziom zorientowania w sprawach integracji wzrastał (Novak, 1998, s. 91). Różnice pomiędzy poszczególnymi partiami dotyczyły już odniesień do konkretnych wydarzeń integracyjnych i strategii akcesyjnej, a także miejsca Republiki Czeskiej w zjednoczonej Europie.

Postawa zwolenników poszczególnych partii politycznych czeskiej sceny wobec integracji Czech z UE wykazywała w latach 90. głębokie zróżnicowanie. Według sondażu FACTUM z września 1997 r., wśród elektoratu głównych czeskich partii politycznych, integracja Republiki Czeskiej z UE miała paradoksalnie najwyższe poparcie wśród elektoratu ODS (79,3\% za) i ODA (Občanská demokratická aliance) (71,8\% za), najmniejsze zaś wśród głosujących na skrajnie prawicowy sojusz SPR-RSC M. Sladka $(33,7 \%)$ i komunistów z KSČM (Komunistická strana Cech a Moravy) 
$(24,6 \%)$ (Novak, 1998, s. 88). W środku plasowały się natomiast pod tym względem KDU-CSL i ČSSD $(45,6 \%)^{4}$.

Dwaj główni oponenci polityczni czeskiej sceny politycznej lat 90., Vaclav Havel i Vaclav Klaus różnili się diametralnie w podejściu do spraw europejskich. Należy jednak podkreślić, że łatwy schemat przeciwstawienia w kwestiach europejskich Havla i Klausa nie wystarcza dla opisania czeskiej sceny politycznej. Ich stanowiska w kwestii integracji były bowiem często mniej przejrzyste niż się wydaje. Przykładowo V. Havel często wyrażał poglądy tyleż nieprecyzyjne co utopijne. W odróżnieniu od L. Wałęsy, uwikłanego w wojnę na górze, Havel, przedstawiający siebie jako federalistę, starał się tworzyć pozytywny obraz kraju za granicą. Jego zdaniem, podstawą rozwoju narodu czeskiego miała być zintegrowana politycznie i ekonomicznie Europa. W swym przemówieniu na forum PE w Strasburgu, w lutym 2000 r., Havel opowiedział się za opracowaniem konstytucji europejskiej i utworzeniem izby wyższej PE („Lidove Noviny", 17.02.2000). Po wygaśnięciu swego mandatu w 2003 r., V. Havel (1993-2003), wycofał się z polityki, ale 15 maja 2003 r. wziął udział w debacie zorganizowanej przez praską fundację Forum 2000, popierając kolejny raz członkostwo Czech w UE. Później, przeciwstawił się rozpisywaniu referendum $w$ sprawie ratyfikacji Traktatu Konstytucyjnego, uważając, że naród już wyraził dlań aprobatę w referendum akcesyjnym.

V. Klaus, który w imieniu Republiki Czeskiej złożył wniosek o przyjęcie do UE, długoletni premier, przewodniczący Izby Niższej parlamentu, a wreszcie prezydent $\mathrm{RCz}$, określał siebie mianem „eurorealisty”. Swoją wizję zbliżenia Czech do Europy, zawarł w książce pt. Czeska droga, w której podkreślał, że jego kraj powinien w drodze do integracji zachować własną tożsamość i funkcjonować jako samodzielna politycznie całość (Rynkowska, 1995, s. 55). Klaus kładł nacisk na rolę państwa narodowego jako obszaru politycznej suwerenności (Munk, 1994). Unię Europejską widział jako organizację międzyrządową współpracującą przede wszystkim na gruncie liberalizacji rynku i handlu. W miarę upływu czasu jego retoryka przybierała coraz bardziej antyeuropejski ksztalt. W czasie wizyty komisarza Guentera Verheugena w Pradze w czerwcu 2000 r., Klaus zaproponował, aby referendum akcesyjne odbyło się w Czechach przed zakończeniem negocjacji, co wprawiło komisarza w konsternację. Uzasadnieniem tego kroku miały być obawy obywateli RCz przed zrzeczeniem się dużej części suwerenności narodowej („Mlada Fronta Dnes”, 2.06.2000). Jednocześnie jednak, znany z eurosceptycznych opinii Klaus, jako jeden z warunków poparcia budżetu na 2000 r. stawiał przyspieszenie przygotowań do wejścia do UE (,GW”, 3.02.2000). U podłoża „eurorealizmu” Klausa jeszcze jako lidera ODS leżała wrogość wobec politycznych aspektów integracji. Jak zauważyła L. Neumayer, w jego postawie wobec UE przeważały trzy motywy: nadrzędność ram państwa narodowego, pochwała różnorodności, której rzekomo zagrażała brukselska administracja oraz krytyka „deficytu demokratycznego"

4 Dane CVVM z lutego 2003 r. pokazały, że elektorat ODS byl nastawiony najbardziej prointegracyjnie (79\%) - KDU-CSL (72\%); CSSD (67\%).

Od nazwy „Manifest eurorealizmu”, dokumentu powstałego w kręgach zbliżonych do wiceprzewodniczącego ODS Jana Zahradila, http://www.zahradil.cz/html/publikace/old/manifest franc.htm. 
w UE. Zastepca Klausa w parlamencie i w ODS, Ivan Langer, stwierdził wiosna 2000 r., że „w porównaniu z Unią Czechy to wysepka wolności” („Gazeta Wyborcza”, 9.08.2000). Daleki od wspierania koncepcji federacyjnego kształtu Europy, Klaus musiał jednak poprzeć wejście Czech do UE, rozumiejąc, że Czechy nie mogą pozostać odizolowaną wyspa. W wywiadzie dla „Die Zeit” stwierdził, że RCz nie ma tak naprawdę wyboru: „Dzisiaj, żaden kraj nie może przetrwać nie będąc członkiem UE, ale mamy liczne pytania co do jej ewolucji i ewolucji jej instytucji" (Deloy, 2000). W oświadczeniu wydanym 10 czerwca $2002 \mathrm{r}$. V. Klaus, jako jedyny z prezydentów krajów kandydujących, nie namawiał rodaków do poparcia Unii, odwołując się jedynie do rozsądku obywateli.

Część pierwszoplanowych polityków Obywatelskiej Partii Demokratycznej (ODS) V. Klausa, zachowywała rezerwę wobec postulatów takich jak „Europa regionów” czy „państwo społeczne”. Obywatelscy demokraci wyraźnie opowiadali się za wizja wspólnej Europy sprzed Maastricht. Ich program postulował przeciwdziałanie osłabianiu wpływu mniejszych państw europejskich w ramach UE ${ }^{6}$. Zdaniem V. Klausa, i wielu innych polityków ODS, UE była też zbyt mało atlantycka („GW” (dalej GW), 15.16.06.2002). Co zrozumiałe, ODS jako partia konserwatywno-liberalna skupiała się na ekonomicznych stronach akcesji, atakując $m$.in. fundusze unijne i generalnie sposób wykorzystywania unijnych środków finansowych („Gazeta Środkowoeuropejska” (dalej GŚ), 25-26.05.1996.). Dla obywatelskich demokratów, entuzjastyczne podejście do akcesji było o tyle nieuzasadnione, że w miarę postępu negocjacji coraz bardziej oddalały się szanse na duże korzyści. Często używanym argumentem było zatem stwierdzenie, że jeśli do UE wejść trzeba, to po to, by wpływać na jej wewnętrzne reformy z korzyścią dla Czech. Intencją ODS było od dawna utworzenie, po wejściu do UE wspólnego frontu z brytyjskimi konserwatystami (Bartak, 2003). Dlatego, w pracach Konwentu obywatelscy demokraci dołączyli do lobby suwerenistów, aby, jak ujął to V. Klaus przed PE, zapobiec przechodzeniu do rozwiązań ponadnarodowych $i$,pełzającej unifikacji kontynentu" "7. Przytoczona wypowiedź wywołała zdumienie tak w Europie, jak i w Czechach. Co warto podkreślić, ostrych wypowiedzi Jana Zahradila i Vaclava Klausa na temat UE nie podzielali wszyscy przedstawiciele ODS. W oficjalnym stanowisku partii Klausa dawało się zauważyć chęć obrony przed zarzutem o wrogość wobec integracji europejskiej, a eurorealizm starano się odróżniać od izolacjonizmu i ksenofobii (Blaha, s. 150). Jeśli chodzi o referendum, ODS poparła, choć bez entuzjaz$\mathrm{mu}$, głosowanie za przyjęciem akcesji.

Zdaniem czeskich politologów, tzw. „eurorealizm” Klausa, przełożył się na słabe przygotowanie kraju do członkostwa, widoczne na etapie screeningu. W latach 1993-1997 aż nadto jaskrawa była bowiem dysproporcja pomiędzy deklaracjami ODS dotyczącymi UE a rzeczywistą polityką (Dančák, 2003). Po utracie władzy, politycy ODS

${ }^{6}$ Program wyborczy ODS z 1996 r., cytat za: V. Kubišová, L'image de l'Union européenne dans la conscience des citoyens tcheques, op. cit., s. 87.

7 Protestując przeciwko przygotowywanej konstytucji europejskiej, czlonek czeskiej delegacji. wiceprzewodniczący ODS J. Zahradil demonstracyjnie opuścil 12 czerwca 2003 r. salę obrad Konwentu w Brukseli, które określił jako ,jedną wielką manipulację". Dwaj pozostali przedstawiciele Czech - Jan Kohout i byly szef czeskiej dyplomacji, Josef Zieleniec - potępili ten gest. 
(tak jak prawica w Polsce wobec rządów SLD czy też FIDESz Viktora Orbána na Węgrzech w stosunku do rządu Pétera Medgyessy) krytykowali rząd za zbyt uległe negocjowanie warunków członkostwa, a później rządową kampanię informacyjną. Przed wyborami do parlamentu z czerwca 2002 r., ODS jeszcze bardziej zaostrzyła swą retorykę, chcąc pozyskać część elektoratu republikanów M. Sladka pozostających od $1998 \mathrm{r}$. poza parlamentem. Obiecywała bardziej zdecydowanie bronić czeskich interesów w stosunkach z UE i ograniczyć napływ cudzoziemców („Rzeczpospolita” (dalej Rzp), 15.05.2002).

Wbrew ideologicznym podziałom, paradoksalnie, ODS i komuniści mieli często zbieżne poglądy na sprawy związane z UE. O ile komuniści krytykowali UE jako dziecko kapitalizmu, Klaus uznawał ją za dzieło socjalistów (Spitkova, 1995). Łączyło ich też wspólne stanowisko wobec Niemiec, zakładające obronę rezultatów II wojny światowej, krytycyzm wobec bombardowania Serbii podczas konfliktu w Kosowie czy też polityki amerykańskiej wobec Iraku. Co ciekawe, przedstawiciele ODS dopuszczali scenariusz powtórki referendum i wejścia Czech do UE w roku 2007, a nawet odrzucenia oferty członkostwa ${ }^{8}$. Przygotowano alternatywną koncepcję czeskiej polityki zagranicznej. „Manifest eurorealistów” J. Zahradila, kandydata ODS na ministra SZ, przedstawiony przez V. Klausa wiosną 2001 r. zakładał na serio możliwość pozostania Czech poza UE, co w Europie Środkowej było dość szczególne dla partii politycznej mającej widoki na sprawowanie władzy („Rzp”, 26.03.2001). Według manifestu, Czechy miały przygotować się na zmianę swej polityki zagranicznej: rewizję umowy stowarzyszeniowej z UE, rozluźnienie związków z Niemcami, na korzyść więzi z USA, brytyjsko-skandynawskiej grupy w UE oraz NAFTA i EFTA („Rzp”, 24.04.2001). Podobną, alternatywną koncepcję polityki na wypadek pozostania Czech poza UE przygotował też Jiři Payne, wiceprzewodniczący parlamentarnej komisji SZ („Rzp”, 26.03.2001).

Krytyczna wobec eurosceptycyzmu ODS była Czeska Partia Socjaldemokratyczna (Č́SSD). W swej strategii wyborczej z 1996 r. ostro krytykowała politykę zagraniczną Klausa i jego skłonność do pouczania Brukselskiej administracji. Socjaldemokraci opowiadali się wówczas za porzuceniem koncepcji samotnej drogi Czech do struktur euroatlantyckich i proponowali utworzenie Ministerstwa Spraw Europejskich (Blaha, 1996, s. 34). Stanowisko ČSSD wobec integracji oparte było na wartościach głoszonych przez pozostałe europejskie partie socjalistyczne i socjaldemokratyczne, a jej program, choćby ten z wyborów 1996 r., był najbliższy filozofii konstrukcji europejskiej, ponieważ odrzucał koncepcję Wspólnoty jako li tylko strefy wolnego handlu i jako jedyny cytował postanowienia Traktatu z Maastricht, akceptując je w całej rozciągłości (Neumayer, 1998, s. 29). Lider ČSSD, Miloš Zeman dla swojej formacji rezerwował określenie „eurooptymistów”. Już jako ugrupowanie rządowe, CSSD musiała stawić czoła negatywnej ocenie Czech zawartej w raportach KE i skupić się na przyspieszeniu procesu akcesyjnego. Elektorat socjaldemokracji był wbrew deklaracjom programowym partii bardziej nieufny wobec członkostwa w UE niż zwolennicy liberałów. Pozornie potwierdzało to teorię mówiąca, że integracja europejska jest procesem stero-

8 Już w lutym 1996 r., premier V. Klaus opowiedzial się za przeprowadzeniem referendum w sprawie wejścia Czech do UE. 
wanym przez elity, w tym przypadku „oświeconą elitę socjaldemokracji” (Wessels, 1993).

Wśród partii reprezentujących przychylne stanowisko wobec głęboko zintegrowanej UE poza CSSD znalazły się US-DEU (Unie svobody-Demokratická unie) oraz KDU-ČSL. Ta ostatnia, a więc czeska chadecja, bliska ideowo niemieckiej CDU, z którą utrzymywała partnerskie stosunki, pojmowała członkostwo w UE jako formę realizacji wartości chadeckich oraz gwarancję dobrobytu w RCz. Jej program stwierdzał brak alternatywy dla Czech i podkreślał osiagnięcia kraju na drodze do Wspólnoty. Udział tej partii w rządzie pozwalał jej odgrywać zasadniczą rolę w procesie przystępowania Czech do UE. Przewodniczący KDU-ČSL, Cyril Svoboda, był zarazem ministrem SZ, a główna część kampanii promującej wejście Czech do UE, znalazła się w rękach Departamentu Strategii Komunikacyjnej kierowanego z ramienia KDU-ČSL przez Janę Adamcovą. Z kolei secesjoniści z Unii Wolności (Unie svobody - US) utworzonej po podziale ODS w 1997 r., chcąc odróżnić się od ODS przedstawiali się jako politycy nastawieni optymistycznie do integracji europejskiej i wyrażali poparcie dla dalszego pogłębiania UE. W programie Unii Wolności nie było jednak wyrażenia „Unia Europejska”, a jedynie wzmianka o strukturach euroatlantyckich, wartościach europejskich i świadomości europejskiej.

W parlamencie czeskim przeciwne wejściu do UE i NATO były dwa ugrupowania: Komunistyczna Partia Czech i Moraw (KSČM) Miroslava Grebeniczka oraz Stowarzyszenie na Rzecz Republiki - Republikańska Partia Czechosłowacji (SPR-RSČ) Miroslava Sladka, wobec których stosowano konsekwentnie towarzyski ostracyzm („GŚ, 17-18.02.1996). Faszyzujące SPR-RSČ, podczas kampanii wyborczej 1996 r. obiecywało rozwiązać sprawę „nieasymilowalnych mniejszości” oraz przywrócić karę śmierci („GS”, 7-8.09.1996). W jego programie wyborczym z tego roku widniały zaledwie dwa punkty dotyczące polityki zagranicznej: uzyskanie od Niemiec reparacji za II wojne światową i rewizja układu pomiędzy RFN i RCz o wzajemnych stosunkach i współpracy. SPR-RSČ negatywnie oceniało też polityczne i ekonomiczne aspekty integracji. „Republikanie”, którzy w 1996 r. uzyskali 8\% wynik, w 1998 r. nie weszli do Parlamentu.

Jak już wspomniano, Komunistyczna Partia Czech i Moraw (KSČM) wychodziła z ideologicznego założenia, że struktury UE są strukturami państw kapitalistycznych i sprzeciwiała się czeskiemu członkostwu w UE. W programie KSČM z 1996 r. Brukselę przedstawiano jako siedlisko ponadnarodowego kapitału oraz instrument polityki niemieckiej, zagrażającej suwerenności narodowej (Kubišová, s. 88). KSČM odrzucała UE z Maastricht i Amsterdamu, domagając się, aby wszelkie decyzje dotyczace polityki zagranicznej, w tym decyzja o przystapieniu do NATO i UE, były podejmowane na drodze referendum. W 1995 roku, partia ta złożyła nawet wniosek w sprawie zorganizowania takiego referendum, które jednak nie doszło do skutku („Lidove Noviny”, 19.05.1995). W 1999 r., komuniści zaczęli szybko zyskiwać w sondażach (20\% jesienią 1999 r.), wyprzedzając KSČM i plasując się na drugim miejscu po ODS (Blaha, 2000, s. 148). Wynikało to częściowo z faktu, że w kontekście proeuropejskiego konsensusu, komuniści byli w gruncie rzeczy jedyną parlamentarną partią otwarcie kontestującą. W kampanii przed referendum władze KSČM zarekomendowały swemu elektoratowi niegłosowanie za wejściem do UE, uznając, że negocjacje nie zapewniły 
wystarczających warunków dla pomyślnej integracji Czech z UE . Było to jak mówiono „czasowe i taktyczne «Nie»” dla integracji europejskiej, ale zgodnie ze słowami wiceprzewodniczącego partii, Jiřri Dolejsa, komuniści pozostali otwarci na integrację europejską. W 2004 r. wprowadzili w wyborach do PE sześciu deputowanych do Konfederacyjnej Grupy Zjednoczonej Lewicy Europejskiej/Nordyckiej Zielonej Lewicy (GUE/NGL), podczas gdy ČSSD ledwie dwóch, co kosztowało premiera Vladimira Špidlę utratę stanowiska.

Europejski czynnik nie pozostawał bez wpływu na ewolucję czeskiej sceny politycznej. Zbliżający się termin wejścia do UE zapewniał trwanie kruchej koalicji rządzącej, opartej na większości jednego głosu w Izbie Poselskiej. Napięcia w koalicji, w której nie brak było rozbieżności programowych, pokonywano z obawy o destabilizację polityczną, groźną w kluczowym okresie dla integracji z Unią. Wejście do UE było też głównym mottem rządu i głównym hasłem kampanii wyborczej US-DEU i KDU-ČSL. Można stwierdzić, że w rządzie V. Špidli, tym, co łączyło koalicjantów, był zatem przede wszystkim proeuropejski kierunek.

\section{Stowackie rozdarcie}

Jeśli chodzi o Słowację, dziesięć lat po pierwszych wolnych wyborach z czerwca 1990 r. jej system partyjny charakteryzował się słabym zakotwiczeniem społecznym partii politycznych, co sprawiało, że brak było więzi pomiędzy ugrupowaniami politycznymi a interesami jasno określonych grup interesu i środowisk wyborców. Przed każdymi wyborami powstawały nowe partie zdolne do uzyskania reprezentacji parlamentarnej (np. w 1998 r. Partia Porozumienia Obywatelskiego - Strana občianskeho porozumenia - SOP - Rudolfa Schustera, rok później partia Smer Roberta Fico). Podobnie jak w Polsce, słowackie partie polityczne nie krystalizowały się czytelnie wobec fundamentalnej linii podziału lewica-prawica ${ }^{10}$. Można za to zidentyfikować kilka innych trwałych $i$ charakterystycznych dla słowackiego systemu partyjnego podziałów. Pierwszym chronologicznie był podział separatyzm/federalizm, następnymi: podział ekonomiczny (zmiany ograniczone/zmiany radykalne), podział moralno-religijny i podział etniczny (słowacki/węgierski).

Słowacki system partyjny rozwijał się jeszcze w ramach wspólnego państwa czechosłowackiego, w latach 1990-1992, stanowiąc system autonomiczny, z powodu braku partii ogólnoczechosłowackiej (celoceskoslovensky) (Rybar, 2000). Po listopadzie 1989 r., nowo powstające partie określały się jako opozycja do Słowackiej Partii Komunistycznej (Komunistická strana Slovenska - KSS, później Strana demokratickej lavice - SDL), która już w styczniu 1990 r. uległa dekomunizacji, pod naciskiem

9 Oprócz komunistów przeciwnikami wejścia do UE były niewiele znaczące grupy i stowarzyszenia, takie jak Alternatywa Eurosceptyczna, Front Ojczyźniany i Zjednoczenie Narodowe. „Rzeczpospolita", 12.06.2002.

${ }^{10}$ Jak zauważa D.-L. Seiler, typologia partii, posługująca się etykietami w rodzaju „konserwatywna”, „radykalna”, , ,chadecka”, „liberalna” czy „socjalistyczna”, z racji ich plynności znaczeniowej, bywa w Europie Środkowej i Wschodniej wyjątkowo mało przydatna do analizy systemów partyjnych, D.-L. Seiler, La comparaison et les partis politiques, op. cit., s. 9. 
„młodej gwardii” Petera Weissa ${ }^{11}$. W tym okresie powstało wiele innych partii. Niektóre przypisywały się do autentycznej lewicy, odcinającej się od komunistycznej przeszłości, ale nie uzyskały znaczącego poparcia wyborczego (Stefunko, 2000).

Większość nowych partii definiowało się jako partie prawicowe ${ }^{12}$. Na tej stronie sceny politycznej znalazła się Słowacka Partia Narodowa (SNS) kierowana przez Jozefa Prokesa (założona 7 marca 1990 r.), która podkreślała w swym dyskursie poparcie dla niepodległości Słowacji. Środek sceny zajął heterogeniczny front antykomunistyczny VPN (Verejnost Proti Násiliu - Społeczeństwo przeciwko przemocy), który odegrał dużą rolę w przemianach, stając się rzecznikiem demokratyzacji, reformy państwa federalnego i reformy ekonomicznej. Ruch Chrześcijańsko-Demokratyczny (Krestansko Demokratické Hnutie - KDH) przedstawiał się z kolei jako partia antykomunistyczna broniąca wartości moralnych chrystianizmu. Powstały też ugrupowania liczące na głosy mniejszości węgierskiej w Słowacji. Wspomniane partie (VPN, KDH) uzyskały miażdżącą większość w Słowackiej Radzie Narodowej (SNR, a później NR SR) oraz w Zgromadzeniu Federalnym.

Rok 1991 był cezurą dla rozwoju politycznego kraju. Tego roku ruch VPN rozpadł się na dwie części. Ruch na rzecz demokratycznej Słowacji (Hnutie za Demockratické Slovensko - HZDS), utworzony przez zdymisjowanego premiera V. Mečiara, natychmiast ustawił się w opozycji do rządu i Obywatelskiej Unii Demokratycznej (Občianska Demokratická Únia - ODU), korzystając z niezadowolenia wyborców z polityki słowackiego i federalnego rządu. Nawet jeśli nie domagał się z początku niepodległości Słowacji, coraz częściej krytykował reformę federalną posługując się argumentami tyleż narodowymi co gospodarczymi. Narodowcy z SNS stosowali jeszcze bardziej radykalną retorykę, podczas gdy VPN/ODU, KDH i trzy partie mniejszości węgierskiej opowiadały się za reformą państwa czechosłowackiego. Partia Lewicy Demokratycznej (SDL) przyjęła pozycję pośrednią, krytykując metody reformy gospodarczej, ale sprzeciwiając się niepodległości Słowacji. W ten sposób, jeszcze przed wyborami 1992 r., ustaliła się polityczna konfiguracja, która przetrwała w dużym zarysie całą dekadę. Wraz z powstaniem niepodległej Republiki Słowacji, dominująca w polityce słowackiej linia podziału separatyzm/federalizm ustapiła miejsca podziałowi meciaryzm/demokracja, który pokrywał się z antagonizmem izolacjonizm/powrót do Europy, a w centrum wyborczych alternacji na Słowacji znajdowała się odtąd kontestacja osoby V. Mečiara.

W chwili uzyskania niepodległości, słowackie partie opozycyjne uległy marginalizacji, a zwycięski w wyborach 1992 r. HZDS i SNS usprawiedliwiały to ich nie dość stanowczą postawą wobec aspiracji niepodległościowych narodu słowackiego. W dwa lata, HZDS i SNS, tworzące nieformalną koalicję rządową, utraciły część swych deputowanych (m.in.: Rudolf Filkus, Milan Kniażko, Roman Kovacz, Josef Moravczik), którzy nie godzili się na autokratyczne praktyki premiera Mečiara i jego sojuszników. Utworzyli oni Unię Demokratyczną (Demokratická Únia Slovenska - DU), która w so-

11 Po zmianie reżimu, KSS (przyszła Partia Lewicy Demokratycznej - SDL) zapoczątkowała proces przeobrażenia się w partię lewicową o charakterze socjaldemokratycznym.

${ }^{12}$ W latach 90, na poziomie ideologicznym dwie trzecie slowackich elit sytuowało się bądź na prawicy bądź na centroprawicy. 
juszu z KDH i SDL, przy poparciu partii węgierskich, doprowadziła do upadku rządu w marcu 1994 r. i przegranych przez opozycję przyspieszonych wyborów. Tendencja do krystalizowania się sceny politycznej wokół linii podziału meciaryzm/demokracja stała się jeszcze bardziej widoczna po 1994 r. (Higley, Pakulski, 2000, s. 671) HZDS i SNS utworzyły koalicję rządowa, do której weszło Stowarzyszenie Robotników Słowackich (Zdrut'enie Robotnikov Slovenska - ZRS), posługujące się retoryką anty-reformatorską i sprzeciwiające się wejściu Słowacji do NATO i UE ${ }^{13}$.

Można uznać, że przeciwnicy integracji dzielili się w Słowacji na trzy grupy. Najliczniejszą stanowili ci, którzy obawiali się utraty świeżo zdobytej suwerenności narodowej. Narodziny niezależnej Republiki Słowackiej stanowiły dla nich najwyższą wartość, znajdującą się ich zdaniem w konflikcie z filozofią UE. W tej uproszczonej wizji integracji, Unia Europejska stanowiła nic innego jak wariant breżniewowskiej doktryny ograniczonej suwerenności (Petruf, 1999, s. 62). Kolejną, niejednorodną grupe ,eurosceptyków” stanowili radykalni przeciwnicy idei integracji, przekonujący do idei własnej słowackiej drogi. I tak na przykład, lider wspomnianego Stowarzyszenia Robotników Słowacji i wiceprzewodniczący słowackiej Rady Narodowej, Jan Luptak przeciwny był wejściu Słowacji do NATO, czemu dał wyraz m.in. w 1995 r., w wywiadzie dla rosyjskiej agencji ITAR-TASS. Stwierdził w nim, że najlepszym rozwiązaniem dla Słowacji byłaby neutralność („GW”, 19.10.1995). Podobne poglądy reprezentował Jan Slota, przywódca Słowackiej Partii Narodowej. Obaj byli przeciwni członkostwu Słowacji w NATO i UE i innych organizacjach międzynarodowych. Wreszcie, trzecią grupę tworzyli politycy, którzy proponowali prowadzenie z zachodnimi demokracjami bardziej złożonej gry politycznej i sondowanie, na jak wiele Bratysława może sobie pozwolić pod względem politycznym i ekonomicznym. Krytyka negatywnych aspektów integracji szła u tych polityków w parze $\mathrm{z}$ oficjalnym wspieraniem dążeń do $\mathrm{UE}^{14}$. Do tej grupy można zaliczyć HZDS Mečiara. Jego nieokreśloność programowa wynikała z faktu, że Mečiar stał na czele ugrupowania, w skład którego weszli nie tylko byli reformatorzy z 1968 r., ale także byli komuniści, czynni przed 1989 r. oraz politycy, którzy w 1990 r. postawili na słowacką niepodległość. Nie przeszkadzało to słowackim wyborcom, ceniącym Mečiara za twardą postawę wobec mniejszości wegierskiej oraz zachodnich polityków krytykujących nadużycia rządu. Do orientacji proeuropejskiej należały wszystkie partie opozycji demokratycznej, krytycznie oceniające izolacje Słowacji na arenie międzynarodowej. $Z$ oczywistych względów, za docelowym przystąpieniem Słowacji do UE opowiadały się partie mniejszości węgierskiej, choć wspierane przez Budapeszt nieraz posuwały się do obstrukcji.

Przed wyborami 1998 r., mnożyły się antydemokratyczne i niekonstytucyjne poczynania partii rządzących. Za wyjątkiem SDL, cała opozycja parlamentarna surowo krytykowała rządy Mečiara, a po skandalu z referendum z maja 1997 r. utworzyła

13 W okresie 1994-1998, ZRS poparło jednak szeroko zakrojoną prywatyzację i przeciwstawiło się autorytarnemu stylowi rządów Mečiara. W 1998 r. ZRS nie zdołało dostać się do parlamentu, uzyskując $1,3 \%$ głosów.

14 Przed planowanym na luty 1997 r. referendum w sprawie członkostwa Slowacji w UE i NATO, za wejściem do UE i Paktu opowiadal się rządzący HZDS V. Mečiara i najsilniejsze partie opozycyjne; przeciwne byly wspólrządzące Slowacka Partia Narodowa i Stowarzyszenie Robotników Slowacji. 
szeroki blok wyborczy, Słowacką Koalicję Demokratyczną (SDK), sojusz KDH, DU oraz trzech małych partii - socjaldemokracji, zielonych i partii liberalno-demokratycznej. HZDS V. Mečiara wygrał wprawdzie wybory z 1998 r., uzyskując o jedno miejsce więcej od SDK, ale poza tradycyjnym partnerem, SNS, nie dysponował innymi sojusznikami. Po ogłoszeniu wyników, powstała zatem koalicja czterech partii SDK, SDL, SMK i SOP R. Schustera. Ich programy w zakresie polityki zagranicznej świadczyły o zmianie dynamiki procesu integracji. Wszystkie partie nowej koalicji rządowej łączyły wspólne przekonania demokratyczne - ambicje wprowadzenia Słowacji do NATO i UE oraz wola kontynuowania przemian gospodarczych. Dysponowały one w Radzie Narodowej większością trzech piątych miejsc, niezbędną dla wprowadzenia ewentualnych zmian w Konstytucji. Jednak niespójność koalicji oraz niekończące się spory utrudniały podejmowanie koniecznych decyzji politycznych. Spór pomiędzy liderem KDH Janem Carnogurskim, a urzędującym premierem Mikulášem Dzurindą na tle ewolucji SDK doprowadził do utworzenia przez Dzurindę nowej partii, Słowackiej Unii Chrześcijańsko-Demokratycznej (Slovenskả Demokratickả a Krestanská Únia - SDKU), przedstawianej jako spadkobierczyni SDK. Ta ostatnia zaczęła natomiast dryfować potem w stronę pozycji bardziej eurosceptycznych.

Po 1998 r. partia Mečiara pozostała w opozycji. Wkrótce potem, Mečiar ogłosił rezygnację z mandatu deputowanego i zamierzał rzekomo wycofać się z życia politycznego. Jednocześnie, na pierwszy plan w HZDS wysunęli się politycy reprezentujący linię umiarkowaną. Sześć miesięcy po wyborach, Mečiar na nowo stanął na czele Ruchu i doszedł do drugiej tury wyborów prezydenckich, w której przegrał z R. Schusterem. Na Kongresie Ruchu, w marcu 2000 r., został ponownie wybrany na lidera partii. Zdołał też polepszyć wizerunek swej partii i położyć kres jej izolacji na scenie politycznej dzięki przeobrażeniu ruchu w centroprawicową partię typu ludowego, zmianie nazwy na LS-HZDS (Ludova Strana - Hnuti za Demockratické Slovenska) i kategorycznemu poparciu dla wstapienia Słowacji do UE i NATO. Miało mu to umożliwić późniejsze wejście do europejskiej formacji chadeckiej, choć J. Čarnogurski, lider słowackich chadeków, którzy już do niej należeli twierdzil, że na to nie pozwoli (Bartak, 2000, s. 12). Jak też wiadomo eurodeputowani LS-HZDS weszli ostatecznie do PE jako niezrzeszeni.

\section{Wegry - losy ponadpartyjnego konsensusu}

Na Węgrzech, w 1990 r., z thumu ruchów politycznych wyłoniło się sześć partii posiadających potencjał koalicyjny. Przez kolejne lata ich liczba praktycznie nie uległa zmianie, a polityczna szachownica wykrystalizowała się wokół czterech najsilniejszych ugrupowań. W pierwszej fazie przemian, dominującą pozycję zdobyło heterogeniczne Węgierskie Forum Demokratyczne (Magyar Demokrata Fórum - MDF), założone w 1987 r. Później, postkomunistyczna lewica wyszła z politycznej izolacji, a proces krystalizacji węgierskiego systemu partyjnego doprowadził do powstania liberalnej Węgierskiej Partii Obywatelskiej - FIDESz ${ }^{15}$, socjaldemokratycznej MSzP

15 Później FIDESz - MPP (sojusz Młodych Demokratów i Węgierskiej Partii Obywatelskiej), zal. 30 marca $1988 \mathrm{r}$. 
(Magyar Szocialista Párt) i socjalliberalnej SzDSz (Szabad Demokraták Szövetsége). Wspomniane cztery ugrupowania odgrywały wiodącą rolę w formowaniu gabinetów rządowych, wchodząc w sojusze $z$ dwoma innymi partiami politycznymi: Ludową Partią Chrześcijańsko-Demokratyczną (Kereszténydemokrata Néppárt - KDNP) i Niezależną Partią Drobnych Właścicieli (Független Kisgazdapárt - FKgP), której głównym hasłem było odtworzenie struktury rolnej z 1947 roku (Lhomel, s. 221). W ciągu dziesięciu lat, władza wykonawcza przechodziła zatem kolejno z rąk konserwatywno-prawicowej większości z czasów J. Antalla do rąk lewicy z Węgierskiej Partii Socjalistycznej w 1994 r., aby powrócić w 1998 r. do ugrupowań liberalnej centroprawicy. W 2001 r. znów do władzy doszła lewica.

Ponadpartyjny konsensus w węgierskiej polityce zagranicznej dotyczył trzech kwestii: integracji ze strukturami euroatlantyckimi, ochrony węgierskich mniejszości za granicą i utrzymywania dobrych stosunków z krajami ościennymi. W latach 90. XX w., władze wegierskie czyniły wszystko, aby uniknąć upolitycznienia kwestii członkostwa w UE. Miało to akcentować wegierską determinacje, na tle wahan strony unijnej. Symptomatyczne było w tym względzie zachowanie partii skrajnych, które choć podkreślały niebezpieczeństwa dla tożsamości narodowej, długo nie ośmieliły się poddawać w wątpliwość samej zasadności aspiracji europejskich Węgier (Capelle-Pogàcean, Goussef, 1997, s. 111). Pewna zmiana nastapiła w 1997 r., a więc w chwili, gdy stało się pewne, że Węgry zostaną wybrane do pierwszej grupy kandydatów. Tendencja eurosceptyczna, najpierw zauważalna $w$ środowiskach pozaparlamentarnych, zaczęła pojawiać się w bardziej umiarkowanej formie na parlamentarnej prawicy.

Można rzec, że w latach 90. na Weggrzech wykrystalizowały się trzy postawy i wizje integracji europejskiej: podejście technokratyczne i entuzjastyczne MSzP-SzDSz ( $M a-$ gyar Szocialista Párt-Szabad Demokraták Szövetsége), bardziej nieufna, ale przychylną integracji postawę FIDESz, MDF i FKgP oraz eurosceptycyzm MIÉP. W odróżnieniu od RCz, Wegry nie posiadały w latach 1994-1998 silnej partii parlamentarnej otwarcie kontestującej integrację kraju ze strukturami UE (Jemnitz, 2001). Tylko dwie partie opowiadały się otwarcie przeciwko przystapieniu Wegier do UE. Pierwszą z nich była powstała w 1990 r. Partia Pracy, spadkobierczyni konserwatywnego skrzydla partii komunistycznej, reprezentująca ortodoksyjny marksizm. Podobnie jak czeska partia komunistyczna, Partia Pracy obawiała się zdominowania kraju przez kapitał zagraniczny. Z kolei Partia Sprawiedliwości i Życia (MIÉP) I. Csurki była populistyczno-nacjonalistycznym ruchem powstałym w 1993 r. po wykluczeniu skrajnych frakcji z MDF. Od poczattku, stanowiła ona zalażek partii eurosceptycznej, której argumentacja pozbawiona była jednak podbudowy intelektualnej. W swym programie łączyła wątki narodowe i agrarystyczne z ideą poszukiwania „środkowoeuropejskiej trzeciej drogi” pomiędzy kapitalizmem a socjalizmem. Integrację Węgier z UE postrzegano w niej jako kolonizację kraju przez Zachód, a celem było budowanie Węgier silnych i niezależnych od zewnętrznych wpływów. Partia ta oskarżała rządzącą koalicję o oszukiwanie Węgrów i poświęcenie niepodległości kraju. Ugrupowanie to, od czasu wyborów z kwietnia 2002 r. pozbawione parlamentarnej reprezentacji, domagało się jednak, wbrew ordynacji wyborczej, przyznania jego członkom funkcji obserwatorów w dniu referendum 12 kwietnia $2003 \mathrm{r}$.

Jeśli chodzi o Partię Drobnych Posiadaczy FKgP, jej lider Jozsef Torgyan znany był z populistycznych ataków na integracyjną politykę lewicowego rządu G. Horna. Obie- 
cywał też, że w imię obrony interesów narodowych, będzie stawiał UE twarde warunki i bronił węgierskiego rolnictwa. Po serii skandali finansowych, w które zamieszani byli jej liderzy z J. Torgyanem na czele, FKgP ewoluowała jednak w stronę bardziej centrowa, a jej stosunek do integracji stał się bardziej przychylny, choć zdystansowany wobec idei federacji europejskiej. FKgP opowiadała się za ograniczeniem kompetencji ponadnarodowych w UE (Neumayer, 1998, s. 11). Inne ruchy polityczne przeciwstawiające się integracji Węgier z UE - Węgierski Ruch Ochrony Terytorium, Ruch Wolnych Węgier, Ruch Lepsze Węgry czy Węgierski Front Narodowy Ernö Rozgonyiego, powstały w wyniku rozpadu MIÉP - twierdziły, że wybierając włączenie się do UE, kraje tej części kontynentu narażają na niebezpieczeństwo własne gospodarki oraz stawiają pod znakiem zapytania nie tylko wolność swych obywateli, ale również suwerenność narodową. Niektórzy przeciwnicy integracji opowiadali się za dalszym tworzeniem pomiędzy państwami Europy Środkowej i Wschodniej strefy wolnego handlu, opartej na modelu monarchii austro-węgierskiej. W kampanii przed referendum zarówno zwolennicy, jak i przeciwnicy integracji powszechnie wykorzystywali zresztą wątki historyczne. Podczas celebrowania w marcu rocznicy rewolucji $1848 \mathrm{r}$. przeciwnicy integracji manifestowali pod hasłem: „Petöfi głosowałby na «nie»”. Burmistrz Budapesztu, Gabor Demszky zapewniał natomiast, że głosując na „tak” Węgrzy pozostaną wierni przodkom i zasadom z $1848 \mathrm{r}$.

O ile największe partie zgadzały się, z różnym entuzjazmem, co do samej orientacji proeuropejskiej, nie brakowało między nimi różnic, jeśli chodzi o sposoby pogodzenia akcesji z innymi priorytetami. Różnicowały się one względem siebie szczególnie na tle stosunku do wartości chrześcijańskich i narodowych. Podczas gdy dla rządu J. Antalla, sprawa węgierskich społeczności żyjących poza granicami kraju była najważniejsza, koalicja, która objęła władzę w 1994 r. uznała politykę poprzedników za nazbyt zideologizowana. W swym programie rządowym, G. Horn deklarowal, że trzy wspomniane cele są jednakowo ważne i stanowią współzależną całość. Choć wyczuleni na kwestie narodowe Węgrzy zdołali uniknąc skrajnego nacjonalizmu. MIÉP I. Csurki uzyskała w wyborach 1998 roku 14 miejsc w parlamencie, a inne ugrupowania stosujące faszyzującą, antysemicką czy antycygańską retorykę nie przekroczyły w żadnych wyborach progu wyborczego.

Dla socjaldemokratów z MSzP, integracja europejska była przede wszystkim historycznym procesem, który doprowadził do powstania konstrukcji społeczno-ekonomicznej będącej zwycięstwem wartości reprezentowanych przez państwo opiekuńcze. MSzP głosiła potrzebę Europy wychodzącej poza strefę wolnego handlu i kładącej nacisk na społeczny wymiar europejskiej rzeczywistości. Związek Wolnych Demokratów (SzDSz) partia intelektualistów o przekonaniach centrolewicowych z elementami liberalizmu ekonomicznego, wspierała wartości zachodnie i integrację europejską opowiadając się za głębszą integracją i Europą polityczną (Kende, 1990, s. 42). Sympatycy koalicji socjalistów i Związku Wolnych Demokratów deklarowali w 81\% głosowanie za czlonkostwem, co znacznie przekraczało średnią krajową.

$\mathrm{Na}$ biegunie centroprawicowym i narodowo-populistycznym sytuowało się Węgierskie Forum Demokratyczne (MDF). Po wyborach 1990 r., MDF i jego sojusznik FKgP, postawiły na odnowę narodu. Łączące różnorodne, a nawet sprzeczne tendencje (populistyczne, katolickie, chadeckie), Forum Demokratyczne stało się później ofiarą 
fragmentacji (Nagy, 1996, s. 100-101). Choć MDF było partią prozachodnią, wyrażało jednak nieprzejednane stanowisko w kwestii węgierskiej diaspory w krajach ościennych. W drugiej połowie lat 90., MDF pielegnowało wizerunek „partii patriotów”. Konserwatyści z MDF, GKgP i KDNP uzasadniali swe poparcie dla UE faktem przynależności Węgier do cywilizacji zachodniej. Podkreślali wagę wartości chrześcijańskich, leżących u podstaw idei europejskiej. Wychodząc z założenia, że suwerenność narodowa jest podstawą ich wizji przyszłości, partie te opowiadały się za „Europą Ojczyzn", a przeciwko daleko posuniętej integracji. Charakterystyczne, że pierwszym rozmówcą Forum wśród partii politycznych na Zachodzie był ruch gaullistowski (Kende, 1990, s. 42).

FIDESz o orientacji centroprawicowej był partią liberalno-demokratyczną przekonaną o konieczności integracji z UE, głównie z powodów pragmatycznych. Dla liberałów z FIDESz, bliskich ideowo konserwatystom brytyjskim (a zatem i ODS V. Klausa), Wspólnota była przede wszystkim rzeczywistością ekonomiczną, przestrzenią praktycznego zastosowania zasad swobodnego handlu i gwarancją nieodwracalności przemian. We wcześniejszych latach FIDESz, partia postrzegana jako młodsza wersja SzDSz, definiował się jako nowoczesne proeuropejskie ugrupowanie o poglądach konserwatywnych. W drugiej połowie 1995 r. skręcił na prawo, zapożyczając konserwatywne akcenty od MDF. Choć początkowo potępiał nacjonalistyczne stanowisko rządu Antalla, później coraz częściej zaczął wspominać o groźbie utraty tożsamości i rzekomej kolonizacji gospodarczej kraju przez zachodnie koncerny (Capelle-Pogàcean, Goussef, s. 98). Podczas wyborów 1998 r., FIDESz-MPP wykorzystywał instrumentalnie tematykę europejską w wewnętrznej walce politycznej (nową koalicję utworzyły wówczas FIDESz-MPP, FKgP i MDF ${ }^{16}$ ) ze szkodą dla ponadpartyjnego konsensusu w polityce zagranicznej. Partia V. Orbána krytykowała strategię koalicji MSzP-SzDSz zmierzającą do członkostwa za wszelką cenę $e^{17}$. V. Orbán, jeszcze jako przewodniczący komisji integracji europejskiej w parlamencie, krytykował UE, twierdząc, że w kontaktach z Europą należy bardziej uwzględnić narodowe interesy Wę$\operatorname{gier}^{18}$. Już jako premier potrafił też zaskoczyć, domagając się ,twardych negocjacji z UE" (Lovász, 1998). Antykapitalistyczne i wrogie wobec Zachodu hasła miały przynieść FIDESz głosy „ofiar przemian” i doprowadzić do zwycięstwa wyborczego, w sojuszu z Csurką i Torgyanem ${ }^{19}$. W miarę zbliżania się wyborów z 2002 r., prawica zaczęła jeszcze bardziej odchodzić od ustalonego konsensusu w sprawie strategicznego celu integracji europejskiej, oskarżając stronę rządową o uległość wobec Brukseli. FIDESz posuwał się do agresywnej kampanii pod adresem zagranicznych koncernów,

${ }^{16}$ W wyborach z maja $1998 \mathrm{r}$. następujace partie polityczne przekroczyly próg wyborczy ustalony na poziomie 5\% oddanych głosów: FIDESz - MPP (Sojusz Mlodych Demokratów - Węgierska Partia Obywatelska), FKgP (Niezależna Partia Drobnych Posiadaczy); MDF (Węgierskie Forum Demokratyczne); MIÉP (Węgierska Partia Sprawiedliwości i Życia); MSZP (Węgierska Partia Socjalistyczna); SzDSz (Związek Wolnych Demokratów).

17 Jak stwierdził Miklós Haraszti, V. Orbán wywrócił porozumienie, którego przez dziesięć lat transformacji trzymali się politycy węgierscy niezależnie od orientacji: „GS’, 28.10.1999.

18 „GW", 30.10 .1998$.

19 FIDESz, FKGP, MDF i KDNP oraz trzy centrale związkowe domagaly się na przykład zakazu sprzedaży ziemi węgierskiej cudzoziemcom, „Le Monde diplomatique”, luty 2000, s. 7. 
kosmopolitów, liberałów i kryptokomunistów. W pewnej chwili Orbán oświadczył wręcz, że ,istnieje życie poza Wspólnotą Europejską" (Gueullette, 2000, s. 80). Po porażce 2002 r., taktyka Orbána polegała na krytykowaniu rządu do ostatniej minuty negocjacji i utrzymaniu suspensu odnośnie decyzji jego partii w sprawie koniecznej do akcesji modyfikacji Konstytucji węgierskiej, która musiała być przyjęta kwalifikowaną większością 2/3 głosów. Premier P. Medgyessy mówił pod koniec 2002 roku, że istniejący w kwestii integracji szeroki konsensus na prawicy i lewicy staną pod znakiem zapytania wskutek postawy Orbána i jego sojuszników: ,w chwili gdy wychodzimy na ostatnią prosta, powstaje dziwny podział: FIDESz mówi wyłącznie o złych stronach akcesji, my zaś o korzyściach!” („Politique Internationale”, nr 98/2002-2003, s. 60). Szef węgierskiej dyplomacji Lászlo Kovacs oskarżył nawet FIDESz o skrytą agitację przeciw wejściu Węgier do Unii.

\section{Polska - konsensus vs głębokie podzialy}

W Polsce (podobnie jak w Słowacji), w większym stopniu niż na Węrzech i w Czechach, osią międzypartyjnej rywalizacji była przeszłość. Podział na partie postkomunistyczne i solidarnościowe miał znaczenie organizujące scenę polityczną (Dwernicki, Zalewski, 1996, s. 18). Spór pomiędzy zwolennikami i przeciwnikami ,powrotu do Europy" często objawiał się jako ideologiczny konflikt liberałów i konserwatystów.

Znaczenie parlamentu w systemie władzy w Polsce sprawiało, że stanowisko poszczególnych partii w konkretnych sprawach polityki zagranicznej winno mieć istotne znaczenie dla funkcjonowania państwa. Jednak rozdrobnienie Sejmu w początku III RP i słabość programowa partii sprawiały, że odgrywał on stosunkowo małą rolę $\mathrm{w}$ procesie budowania ponadpartyjnego konsensusu $\mathrm{w}$ materii integracji ${ }^{20}$. Istotą ponadpartyjnej zgody w polityce zagranicznej były następujące cele: ugruntowanie europejskiej orientacji Polski oraz jej włączanie do zachodnich struktur integracyjnych; współtworzenie nowego ładu europejskiego, w oparciu o współpracę instytucji międzynarodowych; rozwój jak najlepszych stosunków z sąsiadami m.in. poprzez tworzenie nowych powiązań regionalnych. Zgoda na przystąpienie Polski do WE była niemal jednomyślna choć podobnie jak w innych krajach miała charakter powierzchowny, bo dotyczyła tylko celu strategicznego.

Od 1989 r., ugrupowania szeroko rozumianego konsensusu w sprawach polityki zagranicznej, dzieliły się na dwie orientacje, różniące się stosunkiem do Zachodu i poglądami na rolę wartości narodowych i chrześcijańskich. Pierwszą stanowiły partie otwarte na integrację z Zachodem, których stanowiska programowe były zbieżne z priorytetami polskiej polityki zagranicznej. Druga orientacja, której przedstawicielem było np. Zjednoczenie Chrześcijańsko-Narodowe ( $\mathrm{ZChN}$ ) przy całej swej nieufności wobec Zachodu traktowała konsensus jako przejaw kompromisu. Do ugrupowań konsensusu w początku lat 90. zaliczały się Unia Demokratyczna (UD), posiadająca największy wpływ na politykę zagraniczną, oraz Kongres Liberalno-Demokratyczny

${ }^{20}$ W latach 1991-1993 w Sejmie zasiadało aż 18 ugrupowań, a 123 posłów na 460 opuściło swe formacje, aby przyłączyć się do innej albo utworzyć nową. 
(KLD), Sojusz Lewicy Demokratycznej (SLD), Unia Pracy (UP) i Polskie Stronnictwo Ludowe (PSL). Unia Demokratyczna, konsekwentnie opowiadała się za aktywnym udziałem Polski w procesie integracji. Według jej polityków Układ Stowarzyszeniowy stanowił logiczną konsekwencję polskiej racji stanu, a z WE i NATO partia ta wiązała nadzieje na zapewnienie Polsce bezpieczeństwa i rozwoju („GW”, 17.03.1992). Jednoznacznymi zwolennikami integracji Polski z Europą byli też liberałowie z KLD. Podobnie jak politycy UD, opowiadali się oni za przyspieszeniem integracji ze strukturami europejskimi, proponując, by niezwłocznie po dokonaniu ratyfikacji Układu Stowarzyszeniowego Polska wystapiła o pełne członkostwo we WE.

Zmiany ekip rządzących nie zmieniły priorytetów w polityce zagranicznej mimo obaw związanych z powrotem do władzy ugrupowań postkomunistycznych w $1993 \mathrm{r}$. Choć SLD i UP, upatrywały w integracji europejskiej szansę rozwoju Polski, postkomunistyczna część lewicy nieraz zdradzała dostrzegane na Zachodzie skłonności do antyokcydentalizmu, wyznając w kwestii bezpieczeństwa koncepcje „trzeciej drogi”, neutralności czy rozwiazań paneuropejskich („GW”, 28-19.01.1995). Stale afirmowana linia polityczna zakładająca zakotwiczenie Polski w strukturach europejskich wymusiła jednak na formacji postkomunistycznej ewolucję (Michel, 1997, s. 45). Zaraz po wyborach 1993 r., komisja partii koalicyjnych przygotowała deklarację, zmieniającą ich stanowisko w sprawach polityki zagranicznej, m.in. wobec członkostwa w NATO. Zmianę tę przyspieszyły wydarzenia w Rosji z października 1993 r., lecz ważniejszą przyczyną wydaje się obawa przed izolacją polityczną w Europie i w regionie.

W Polsce żadna z partii nie mogła ignorować jednej piątej społeczeństwa żyjącego z rolnictwa. Dlatego elektorat wiejski znalazł na scenie politycznej licznych obrońców. Przykład PSL pozwala zaobserwować, jak konkretne kwestie związane z przystąpieniem do UE ujawniały postawy antyeuropejskie, kontrastujące z retoryką programową. Pozycja PSL od początku transformacji była delikatna, z powodu fundamentalnych sprzeczności jej charakteru klasowego. Politycy PSL zdawali sobie sprawę z nieuchronności członkostwa w UE i konieczności modernizacji polskiej wsi. Ta ostatnia musiała jednak wpłynąć na kurczenie się wiejskiego elektoratu (Błahut, 1993). W początku lat 90., w programie PSL pojawił się, co zrozumiałe, postulat renegocjacji niektórych niekorzystnych dla strony polskiej ustaleń Układu Europejskiego Polska-WE, zwłaszcza w dziedzinie towarów rolno-spożywczych (Stachura, 1992). W okresie negocjacji, ludowcy opowiadali się za twardą obroną interesów polskiej wsi, a ich postawa opierała się na założeniu, że konieczna jest ochrona gospodarki, a w szczególności rolnictwa przed wykupem ziemi i presją konkurencyjną ze strony UE (Kucharczyk, 1998). Generalnie, partia ta nie była otwarcie wroga przystapieniu Polski do UE, zwłaszcza że w sprawach rynku rolnego zawsze opowiadała się za silnym interwencjonizmem. Politykom PSL zarzucano nawet, a KE nie omieszkała sygnalizować problemu, chęć przejęcia kontroli nad dystrybucją europejskich środków finansowych, poprzez obsadzenie kluczowych stanowisk w agencjach związanych z FEOGA.

Monopol ludowców z PSL na wsi został zachwiany w wyborach 1997 r. przez SLD i AWS, ale ich najgroźniejszym konkurentem stała się Samoobrona, obecna na scenie politycznej od 1992 r., która w wyborach 2002 r. uzyskała 10\% głosów i nie przestała rosnąc w sondażach, aż do wyborów do PE w 2004 r. Populistyczna Samoobrona w swych wystąpieniach broniła gospodarczej i politycznej suwerenności RP przed 
agresywną polityką międzynarodowych korporacji i instytucji finansowych - instrumentów obcych interesów (Nalewajko, 2003, s. 61). Dla A. Leppera pomoc finansowa UE była formą kolonializmu, a alternatywą dla członkostwa Polski w UE miała być swoista ,trzecia droga": autarkia gospodarcza i ściślejsze więzi z rolniczą Europą Środkowowschodnią. W $2001 \mathrm{r}$. Samoobrona widząc, że licytowanie się na antyunijny radykalizm z innymi antyeuropejskimi ugrupowaniami do niczego nie prowadzi, złagodziła na pewien czas swe wystąpienia, okré́lając się jako „partia eurorealistów”. W 2003 r. Samoobrona uznała, że przystapienie do UE na wynegocjowanych warunkach trwale skazuje Polskę na rolę kraju trzeciej kategorii, który „w sposób półkolonialny będzie dostarczycielem młodej kadry pracowniczej dla starzejących się społeczeństw UE i rynkiem zbytu nadwyżek produkcyjnych krajów UE". Zdaniem Samoobrony, renegocjacji wymagały takie zagadnienia jak: kwoty produkcyjne, sprzedaż ziemi, dopłaty bezpośrednie, swoboda podejmowania pracy ${ }^{21}$.

Rozbieżność postaw polskich partii prawicowych wobec integracji skupiła się niczym w soczewce w platformie AWS powstałej w połowie $1996 \mathrm{r}$. Spoiwem ugrupowania był jedynie wspólny rodowód antykomunistyczny. Obecność w AWS formacji ultraprawicowych i antyeuropejskich sprawiała, że nie było w Akcji programowego porozumienia w kwestii integracji (Krauze, 1997/1998, s. 228). Wspólną cechą polskiej prawicy była niechęć do perspektywy tworzenia ściślejszych form integracji europejskiej, zwłaszcza, że wspierały ją siły socjaldemokratyczne i liberalne. Nacjonaliści, ludowcy i niektóre sily konserwatywne, dla których koncepty narodu i państwa miały charakter doktrynalny. Za nadrzędną wartość uznawali suwerenność, której nie można się było wyrzec na rzecz organizacji ponadnarodowej. Postulowali, by proces integracji kraju z Europą łączył się z utrzymaniem przez Polskę tradycyjnych atrybutów suwerenności. W swych deklaracjach programowych $\mathrm{ZChN}$ opowiadało się za udziałem Polski w Europie rozumianej jako „Wspólnota Ojczyzn”. Rzecznik ZChN, Ryszard Czarnecki w 1992 r. wyrażał zastrzeżenia dotyczące integracji politycznej: „Naszym zdaniem np. koncepcja Stanów Zjednoczonych Europy może stać się groźna dla Polski. Opowiadamy się za koncepcją Charlesa de Gaulle'a - Europy ojczyzn” („GW”, 17.03.1992). Wiele ugrupowań prawicowych, z ZChN na czele, głosiło za Kościołem katolickim sprzeciw wobec liberalnego indywidualizmu niosącego relatywizm moralny oraz koncepcje budowania nowego ładu społecznego i państwowego na zasadach etyki katolickiej. Podobnie jak politycy innych umiarkowanych ugrupowań prawicowych - Porozumienia Centrum, Forum Prawicy Demokratycznej, Partii Chrześcijańskich Demokratów, Ruchu Stu, Zjednoczenia Polski - Ruchu dla Rzeczpospolitej - „eurorealiści” z ZChN ${ }^{22}$, widzieli w członkostwie w UE, możliwość wpływania na kształt integracji europejskiej i dbania o przetrwanie modelu państwa narodowego.

Partie narodowe i konserwatywne o charakterze umiarkowanym miały odmienne od liberałów zdanie, jeśli chodzi o tempo procesu integracji. Podczas gdy liberałowie opowiadali się za jak najszybszym wchodzeniem do UE, przy jak najmniejszej liczbie

${ }^{21}$ Stanowisko Partii Samoobrona RP w sprawie przystapienia Polski do Unii Europejskiej na wynegocjowanych warunkach, Warszawa, maj 2003.

${ }^{22}$ Określenia tego użyto w programie ZChN z marca $2002 \mathrm{r}$. Za „eurorealistów" uznawali się też członkowie Samoobrony. 
derogacji, politycy partii prawicowych podkreślali potrzebę uprzedniego przygotowania Polski do członkostwa. Wiceprzewodniczący AWS i lider ZChN, Marian Piłka, uważał, że polityka polegająca na jak najszybszym dążeniu do integracji z UE nie bierze pod uwage jej kosztów (Madera, 2003, s. 180). 9 lipca 2000 r., na konwencji AWS, M. Krzaklewski, skrytykował SLD i UW za ideologiczne podejście do integracji z UE i spychanie na dalszy plan polskich interesów.

Odwołujące się do różnych tradycji ideologicznych (choćby endeckich) partie radykalnej prawicy - często słabe, pozbawione dostępu do środków przekazu i wpływu na politykę zagraniczną - traktowały wejście Polski do UE jako rodzaj „nowej niewoli”. Podobnie jak w Czechach, szczególną uwagę zwracano przy tym na zagrożenie niemieckie, jako że UE postrzegana była często jako instrument niemieckiej ekspansji w EŚ (Śliwa, s. 156). Obawiano się hegemonii, już to niemieckiej (obawy większości sił prawicowych choć nie tylko ${ }^{23}$ ), już to judeogermańskiej (np. Stronnictwo Porozumienie Polskie) (Rogowska, s. 161-169). Negocjacje członkowskie przedstawiane były przez partie anty-europejskie jako chęć upokorzenia Polski i próba przyznania Polsce statusu członka drugiej kategorii. W programie J. Łopuszańskiego (Porozumienie Polskie) „Wybieram niepodległą Polskę” pisano: „Z najgłębszym niepokojem obserwujemy rozwój Unii Europejskiej, w której dostrzegamy elementy tej samej groźnej utopii - z jej ponadpaństwowymi decyzjami i niszczeniem suwerenności narodów, etatyzmem, centralizmem zarządzania gospodarczego, walką z tradycyjnymi wartościami Zachodu wyrastającymi z dorobku kultury klasycznej i przesłania Ewangelii” („GW”, 26.09.2000). W wypowiedziach polityków wrogo nastawionych do integracji Polski z UE brakowało realnych propozycji alternatywnych, a proponowane rozwiązania, w zależności od ugrupowania, sprowadzały się do utrzymywania współpracy z krajami Europy Środkowej i Wschodniej, w tym z Rosją i Ukraina. Charakterystyczne pod tym względem były koncepcje Konfederacji Polski Niepodległej (KPN) z pierwszej połowy lat 90 . KPN, przeciwna ratyfikacji stowarzyszenia Polski z WE, uważała, że bezwarunkowe poparcie dla idei integracji Polski z UE rozmija się z rzeczywistością. Jej lider, Leszek Moczulski proponowal tworzenie pod wodzą Polski i Ukrainy alternatywnej wobec integracji z UE wspólnoty państw Międzymorza („GW”, 13.05.1994). Osobne miejsce na scenie politycznej zajmowała Unia Polityki Realnej (UPR), dla której integracja europejska była przejawem tzw. „euro-socjalizmu”. Zdaniem lidera UPR, Janusza Korwina-Mikke, alternatywą dla członkostwa w UE było przystapienie Polski do NAFTA.

W 1995 r., podczas wyborów prezydenckich, stanowiska najważniejszych kandydatów wobec integracji z NATO i UE byly do siebie bardzo zbliżone. Ówczesna debata nad integracją jak i ta z okresu wyborów do Sejmu w 1997 r. były nader wąte, ponieważ rzeczywista dyskusja prowadziła do nieuchronnej rekompozycji sceny politycznej, a politycy nie byli na nią jeszcze przygotowani. W kampanii wyborczej z 1997 r., widać było, że kandydaci poszczególnych ugrupowań mają w tym względzie trudności

23 J. Dobrosz z PSL mówil w Sejmie w marcu 2002 r., że dla PSL nie do przyjęcia jest koncepcja Europy sfederalizowanej, która powstała w Berlinie. Scenariusz ten przypominal, według niego, niemieckie plany zjednoczenia Europy z początku XX w., gdzie Polska miała być wyłącznie zapleczem dla niemieckiej Europy. 
z odróżnieniem się od siebie (Higley, Pakulski, s. 668). Znaczna polaryzacja wystapiła w okresie negocjacji członkowskich. W wyborach prezydenckich $2000 \mathrm{roku}$, jednoznacznie za integracją Polski z UE opowiadali się tylko A. Olechowski, A. Kwaśniewski i L. Wałęsa. Jarosław Kalinowski z PSL, M. Krzaklewski z AWS, Jan Olszewski z ROP-PC i Piotr Ikonowicz z PP wyrazili poparcie bardziej warunkowe ${ }^{24}$. Pozostali kandydaci - Andrzej Lepper, Jan Łopuszański z Porozumienia Polskiego, Tadeusz Wilecki i Dariusz Grabowski z Koalicji dla Polski - wypowiedzieli się przeciwko wstępowaniu Polski do UE, a gen. Wilecki domagał się wręcz natychmiastowego zerwania negocjacji akcesyjnych.

W kampanii parlamentarnej $2001 \mathrm{r}$. toczącej się w kontekście wyraźnej radykalizacji życia politycznego i rosnącej konkurencji pomiędzy partiami antyeuropejskimi, kilka ugrupowań - Przymierze dla Polski, Alternatywa i Liga Polskich Rodzin - opowiedziało się już nie tylko przeciw integracji Polski z UE, ale wręcz za renegocjacją lub zerwaniem Umowy Stowarzyszeniowej. W Sejmie wyłonionym w 2001 r. zorganizowane siły antyeuropejskie liczyły ponad 90 posłów, co w stosunku do wcześniejszej kadencji stanowiło kilkukrotny wzrost. Już w Sejmie III kadencji nie brakowało polityków otwarcie sprzeciwiających się wejściu Polski do UE. (np. Porozumienie Polskie Jana Łopuszańskiego czy klub parlamentarny Alternatywa), jednak w 2001 r. środowiska te połączyły się w nowo utworzonej LPR, dla której elity władzy składały się ze zdrajców powodowanych intencją zniszczenia Polski. Choć LPR była silnie wspierana przez niektóre środowiska Kościoła katolickiego skupione wokół „Naszego Dziennika” i Radia Maryja, antyeuropejska retoryka tej partii stała w niezgodzie z oficjalną linią Episkopatu Polski, który od 1997 r., czyli wizyty polskich biskupów w Brukseli, „rozpoczął konstruktywny i otwarty dialog z instytucjami Unii” („GW”, 6.11.1997). Pewnym paradoksem było to, że według badań z 2000 r. 84\% księży katolickich w Polsce opowiadało się za wejściem Polski do UE wobec tylko 54\% ogółu społeczeństwa (Drweski, s. 24). Kościół poparł integrację, ale jednocześnie wyrażał nadzieję, że tworząca się Europa przyjmie postać „Europy Narodów”, uwzględni w swej konstytucji odniesienie do chrześcijańskich korzeni Europy i będzie wprowadzać zasady społecznej nauki Kościoła ${ }^{25}$. Taka postawa Kościoła wytrącała oręż z ręki radykalnych eurosceptyków, którzy jak LPR zwalczali idee integracji europejskiej z pozycji klerykalnych.

W wyborach do PE, bilans korzyści i kosztów wynikających z członkostwa Polski w UE przedstawiany był głównie w perspektywie ekonomicznej. Wśród ugrupowań opowiadających się za integracja, na podstawie analizy programów wyborczych wyróżnić można było dwa zasadnicze sposoby definiowania tego procesu. SLD-UP, AWSP, UW i PO udzielały bezwarunkowego poparcia dla integracji. Uzasadnieniem

24 J. Olszewski mówił we wrześniu 2000 r., że warunkiem wejścia do UE musi być gwarancja zachowania polskiej własności ziemi oraz utrzymanie w polskich rękach dyspozycji w takich strategicznych dziedzinach jak system bankowy, energetyka i telekomunikacja. P. Ikonowicz mówił, że do Unii trzeba wchodzić z obawy przed międzynarodowym kapitalem, ale bez ulegania europejskim komisarzom.

${ }^{25}$ Już w 1999 r., Jan Paweł II w swym wystapieniu przed połączonymi izbami polskiego parlamentu, mówil, że Watykan wspiera integrację Polski z UE, a doświadczenie narodu polskiego, jego bogactwo duchowe i kulturalne mogą być wkładem do europejskiej rodziny. Por.: J. Czaja, Stolica Apostolska wobec procesów integracyjnych w Europie, „Studia Europejskie” 2001, nr 1, s. 96. 
poparcia dla integracji powinny być wymierne korzyści ekonomiczne. W tym przypadku głównym punktem odniesienia w relacjach z Unią jest maksymalizacja zysków własnego narodu. Obok tego celu, wymieniana była także potrzeba samodzielnej pracy, która będzie warunkiem powodzenia procesów integracyjnych (UW, PO).

Samoobrona i LPR kwestionowały członkostwo. W programie LPR znalazł się postulat zachowania pełnej autonomii kraju. W 2001 i 2002 r. partie centroprawicowe (PO, UW) i lewicowe utrzymywały, że korzyści z członkostwa przewyższą ewentualne koszty ${ }^{26}$. Partie bardziej sceptyczne - ZChN, PiS, PSL - nie przeciwstawiły się otwarcie integracji, ograniczając się do manifestowania swej rezerwy. Dla PiS, sceptyczna postawa wobec integracji była środkiem na zdyskredytowanie rządzącego SLD i jego polityki „pozbawionej ducha suwerenności”, oraz doktryny europejskiej opartej na krytyce błędów ,stronnictwa białej flagi i lobbystycznych układów"27. Eurosceptyczne partie parlamentarne i pozaparlamentarne posługujące się racjonalnymi argumentami określały tzw. „minimalne warunki”, przy których można było, z ich punktu widzenia, zaakceptować członkostwo Polski w UE. Zarówno PiS jak i ROP domagały się adekwatnego dla demograficznej wielkości miejsca Polski w instytucjach UE, zapewnienia polskiej własności na ziemiach zachodnich i północnych kraju oraz wystarczających transferów środków finansowych z budżetu UE na modernizację kraju, w tym szczególnie rolnictwa. Dlatego też z zadowoleniem przyjęly postanowienia nicejskie i ostro sprzeciwiały się ich zmianom w projekcie Traktatu Konstytucyjnego.

Typowe dla momentu akcesji rozchwianie postaw społecznych, niepewność co do wpływu członkostwa na poziom życia obywateli, atmosfera małostkowych targów w ostatniej fazie negocjacji i działalność Konwentu, niejednokrotnie postrzegana jako kolejna, niedemokratyczna próba przeforsowania ponadnarodowych rozwiązań przez „europejskie elity”, sprzyjały, jak już wspomniano, wzrostowi poparcia dla partii mniej lub bardziej otwarcie sprzeciwiających się członkostwu w UE. Nic dziwnego zatem, że w Czechach i w Polsce, przewagę w wyborach do PE uzyskały formacje eurosceptyczne co przełożyło się na głosowanie nad raportem w sprawie Traktatu Konstytucyjnego w styczniu 2005 r.: Polscy i Czescy eurodeputowani zagłosowali w większości za odrzuceniem raportu.

\section{Konkluzje}

Zróżnicowanie postaw środkowoeuropejskich elit politycznych i elektoratów odbyło się wokół fundamentalnych podziałów sceny politycznej Steina-Rokkana, modernizacja / naród, gospodarka rynkowa / gospodarka sterowana, pracodawcy/ pracobiorcy (Neumayer, 1999, s. 153). Z czasem jednak, również tematyka „europejska”, jako jedna $\mathrm{z}$ linii konfliktu, stała się punktem odniesienia w wewnętrznej grze politycznej. W ewolucji partyjnych postaw wobec integracji z UE istotną rolę odgrywało nastawie-

${ }^{26}$ Por.: Unia Europejska - wykorzystać szansę, Deklaracja programowa VI Kongresu Unii Wolności (16.02.2002).

27 Europa solidarnych narodów, program polityki europejskiej PiS, Uchwala nr 1/23/05/2004 Zarządu Glównego PiS z dnia 28.05.2004 r., http://www.pis.org.pl/dokumenty/program_pe.htm. 
nie elektoratu. W niektórych przypadkach można było zaobserwować istotne rozbieżności. I tak, zarówno w przypadku ČSSD (Česká strana sociálnè demokratická) i KDU (później KDU-ČSL: Křestansko-demokratická unie - Československá strana lidová) w Czechach, jak i w przypadku SLD w Polsce, elektorat przejawiał nastawienie wyraźnie bardziej eurosceptyczne niż oficjalne stanowiska tych partii, co jednak nie wpływało na zmiany zachowań polityków. Odwrotne zjawisko polegające na tym, że niektóre partie powściagliwe wobec przystąpienia do UE popierane były przez elektorat nastawiony bardziej proeuropejsko występowało w przypadku Unii Polityki Realnej (UPR) w Polsce, a w Czechach dotyczyło to ODS (Obćanská demokratická strana). Podziały te szły również w poprzek ugrupowań, przy czym często to przywódcy byli najbardziej przekonani o konieczności szybkiego członkostwa w UE, w kontraście do struktur regionalnych ČSSD (Stadtmüller, 1998, s. 292). Według badań przeprowadzonych przez Demoskop w lipcu 2000 r., najbardziej przychylni członkostwu Polski w UE byli zwolennicy Unii Polityki Realnej (UPR - 90\%), Unii Wolności (89\%), Akcji Wyborczej Solidarność (AWS) (73\%), Unii Pracy (UP) (71\%) oraz Sojuszu Lewicy Demokratycznej (SLD) (69\%). Integrację z Unią popierało ponadto $60 \%$ elektoratu Krajowej Partii Emerytów i Rencistów, 57\% - Ruchu Odbudowy Polski (ROP), 48\% - Polskiego Stronnictwa Ludowego (PSL) oraz 40\% Samoobrony ${ }^{28}$.

Identyfikacja pro- $\mathrm{i}$ antyeuropejskich postaw $\mathrm{w}$ życiu politycznym nie zawsze była sprawą łatwą, ponieważ profil środkowoeuropejskich formacji politycznych często zależał od tworzących je osobistości, a programy partii niejednokrotnie nie nadążały za zmianami w otoczeniu zewnętrznym, szczególnie w pierwszym okresie postkomunizmu. W postawach partii i elektoratów można wyróżnić trzy zasadnicze orientacje: „pro-europejską”, , anty-europejską” oraz „euro-sceptyczną”. Dotyczyły one zarówno spraw polityki wewnętrznej, stosunków z pozostałymi krajami europejskimi jak też docelowego modelu integracji europejskiej. Euroentuzjaści przekonywali do przyspieszenia reform wewnętrznych i jak najszybszego wejścia do UE, przy jak najmniejszych derogacjach. $Z$ kolei eurosceptycy skłaniali się do występowania o jak najdłuższe okresy przejściowe, które pozwoliłyby kontynuować reformy już po rozszerzeniu (Neumayer, 1999, s. 157). Dyskurs proeuropejski opierał się do pewnego stopnia na argumentach emocjonalnych, akcentując korzyści wynikające z członkostwa i stawiając znak równości pomiędzy UE, a rozwojem i modernizacją. Wejście do UE przedstawiane było jako naturalna i bezalternatywna gwarancja demokratyzacji i przekształceń gospodarczych (Stolarczyk, 1999, s. 80-91). Różnica między dyskursem antyeuropejskim a dyskursem eurosceptycznym (i proeuropejskim) polegała na istnieniu alternatywy dla integracji z UE lub jej braku. Bardziej nieokreślona była orientacja eurosceptyczna, która opierała się nie na otwartej kontestacji akcesji, a często na podwójnym dyskursie i krytykowaniu negocjowanych warunków członkostwa w UE. Dobra organizacja eurosceptyków i ich silny posłuch u opinii publicznej nie stanowiły specyfiki krajów EŚW. Argumenty wysuwane przez przeciwników integracji w krajach Europy Zachodniej i w krajach kandydujących nie różniły się od siebie. Były to zwykle obawy o utratę suwerenności, o obniżenie poziomu życia i odebranie dotychczasowych praw. Warto

28 Źródło: Departament Unii Europejskiej i Obsługi Negocjacji Akcesyjnych, MSZ RP. 
też wspomnieć postawę zwolenników radykalnego liberalizmu ekonomicznego (niektórzy politycy ODS, dla których acquis communautaire stanowił zbiór szkodliwych barier). Eurosceptycy obawiali się nie tyle samej akcesji co złego przygotowania i nadmiernego pośpiechu. Chętnie używali oni etykiety „eurorealistów”, co sytuowało ich w pozycji przedstawianej jako mniej bezkrytyczna. Warte podkreślenia jest to, że choć w okresie negocjacji członkowskich dyskurs eurosceptyczny i antyeuropejski stawały się bardziej rozpowszechnione, zjawisko to nadal nie łączyło się z pogłębioną debatą na temat integracji. Dyskurs antyeuropejski opierał się przede wszystkim na przekonaniu o zagrożeniu dla narodu i istnieniu alternatyw wobec wspólnej Europy. Ogólnie rzecz biorąc, zarówno partie skrajnej lewicy, jak i skrajnej prawicy zarzucaly ekipom rządzącym serwilizm względem Brukseli, odwołując się do ciemnych kart historii narodowej (rozbiory, aneksja z 1938 r., traktat z Trianon czy arbitraż wiedeński), a proponowane alternatywy dla członkostwa w UE szły od koncepcji „trzeciej drogi”, przymierza z Rosją i innymi krajami słowiańskimi, poprzez idee Międzymorza, aż do pomysłów na przyłączenie się do NAFTA.

\section{Bibliografia}

Adler A., Est: le vrai-faux retour des communistes, „Politique Internationale”, nr 62, zima 93/94.

Andor L. (2000), La Hongrie dans l'antichambre de l'Europe, „Le Monde diplomatique”, luty.

Bartak K. (2003), La Tchéquie fait ses comptes européens, „Le Monde diplomatique”, marzec.

Bartak K. (2000), Slovaquie, l'image brouillée, „Le Monde diplomatique”, kwiecień.

Blaha J. (2000), République tchèque 1999-2000. Un jeu politique complexe en attendant l'embellie économique, „Le courrier des pays de l'Est", nr 1006, czerwiec-lipiec.

Blaha J. (1996), République tchèque: l'improbable alternance, „La Nouvelle Alternative”, nr 41.

Blahut K. J. (1993), Problemy polskiego rolnictwa w programach wybranych partii politycznych a integracja z EWG, w: Transformacja rolnictwa polskiego w perspektywie integracji ze Wspólnotami Europejskimi, red. A. Marszałek, Wyd. Uniwersytetu Łódzkiego, Łódź.

Capelle-Pogàcean A., Goussef C. (1997), Hongrie, w: L'Europe médiane - au seuil de l'Europe, L'Harmattan, Paris.

Czaja J. (2001), Stolica Apostolska wobec procesów integracyjnych w Europie, „Studia Europejskie”. nr 1.

Czernicka K. (2002), L'Eglise catholique polonaise et le débat européen, „,Regards sur l'Est”, nr 31, październik-listopad.

Dančák B. (2003), Tematyka europejska i czeskie partie polityczne, „Przegląd Środkowoeuropejski”. nr 33, kwiecień.

Deloy C., Le référendum sur l'Union Européenne en République tchèque, http://www.robert-schuman.org/oee/tchequie/referendum/default.htm.

Demokracje Europy Srodkowej w perspektywie porównawczej (1998), red. A. Antoszewski, R. Herbut, Wyd. Uniwersytetu Wroclawskiego, Wrocław.

Drweski B., l'Eglise dans une Pologne désenchantée, „Le Courrier des Pays de l'Est”, nr 1017.

Dwernicki K., Zalewski F. (1996), Pologne: consolidation à gauche et émiettement à droite, „La Nouvelle Alternative", nr 41. 
Gueullette A. (2000), Hongrie 1999-2000. Un pouvoir controversé, malgré de bons résultats économiques, „Le courrier des pays de l'Est”, nr 1006, czerwiec-lipiec.

Higley J., Pakulski J. (2000), Jeux de pouvoir des élites et consolidation de la démocratie en Europe. "Revue française de Science politique", nr 4-5, sierpień-październik.

Jemnitz J. (2001), Przeglad polityki wegierskiej, w: Europa Srodkowa w ostatniej dekadzie XX w., Wyd. Akademii Pedagogicznej w Krakowie, Kraków.

Kende P. (1990), Hongrie: de la réforme à la transformation, „Politique Etrangère”, nr 1.

Krauze J. (1997/1998), Varsovie à l'heure de l'alternance, „Politique Internationale”, nr 78.

Kubis̄ová V. (2001), L'image de l'Union européenne dans la conscience des citoyens tchèques, w: L'Elargissement de l'UE, E. du Réau, Presses de la Sorbonne Nouvelle, Paris.

Kucharczyk J. (1998), Political Parties Towards Prospects for European Integration: „, Yes and Furthermore, No", Report to the Institute of Public Affairs, Warszawa.

Lengyel L. (wywiad), (1998), Zbyt wiele obietnic, „Gazeta Wyborcza”, 30.10.

Lhomel E. (2001), Le pluralisme politique - de l'émergence à la consolidation, „Le Courrier des Pays de l'Est", nr 1013, mars.

Lovász Á. (1998), Orbán calls for firmness toward EU, „The Budapest Sun”, December 10, vol. VI. Issue 49.

Madera A. (2003), Unia Europejska jako Europa Ojczyzn w retoryce Akcji Wyborczej Solidarnośc, w: Europa $i$ integracja europejska w polskiej myśli politycznej XX w., red. J. Juchnowski, J. Tomaszewski, Wyd. Uniwersytetu Wroclawskiego, Wrocław.

Malgaj M., Vrečar B. (2001), Negocjacje w sprawie czlonkostwa Slowenii w UE. Aspekt spoleczno-polityczny, w: Negocjacje akcesyjne - wybrane zagadnienia. Raport przejściowy, Instytut Europejski, Lódź.

Medgyessy P. (wywiad), (2002-2003), „Politique Internationale”, nr 98.

Michel P. (1997), L'Europe médiane, L'Harmattan, Paris.

Mink G., Szurek J.-Ch. (1992), Cet étrange post-communisme, rupture et transition en Europe centrale et orientale, wyd. La Découverte.

Mink G., Szurek J.-Ch. (1995), Europe centrale: la revanche des néo-communistes, „Politique Internationale", nr 67, wiosna.

Munk E. (1994), Skeptics Debate the Wisdom of European Union Admission, „The Prague Post”, 7.12.

Nagy L. (1996), La transition hongroise de 1990 à 1996. De la république des professeurs à la république des camarades. Georg. Genève.

Nalewajko E. (2003), Le débat polonais sur l'intégration, w: La Pologne et l'intégration européenne, red. J.-M de Waele, Wyd. Université de Bruxelles, Bruxelles.

Neumayer L. (1999), Opinions publiques et partis politiques face à l'intégration européenne, „Revue d'études comparatives Est-Ouest", vol 30, nr 1

Neumayer L. (1998), Les partis politiques et l'intégration européenne, „La Nouvelle Alternative”, nr 49, mars.

Niedermayer (1993), Public Opinion and International Governance, Oxford University Press.

Novak M. (1999), L'Union Européenne vue de Prague, w: L'Elargissement de l'Union européenne à l'Est européen. Enjeux historiques et perspectives, Université de Cergy-Pontoise. (CCIC). lipiec.

Petruf P. (1999), La Slovaquie et l'Union européenne: déterminants historiques, positions actuelles, w: L'Elargissement de l'Union européenne à l'Est européen. Enjeux historiques et perspectives. Université de Cergy-Pontoise. (CCIC), lipiec. 
Potel J.-Y. (1996), Stabilisation politique en Europe centrale. Consensus des modérés, montée des démagogues, „Le Monde diplomatique”, listopad.

Potel J.-Y. (1994), Le retour des communistes en Europe de l'Est , „Le Monde diplomatique”, styczeń.

Ramonet I. (1993), Polonaises nostalgies, „Le Monde diplomatique”, październik.

Reschova J. (1997), EU and the Czech Parliament, Budapest Papers on Democratic Transition, Hungarian Center for democratic Studies, Budapest.

Rogowska B. (2003), Partie prawicowe wobec integracji europejskiej w latach 1989-1998, w: Europa i integracja europejska w polskiej myśli politycznej XX wieku, red. J. Juchnowski, J. Tomaszewski, Wyd. Uniwersytetu Wroclawskiego, Wrocław.

Roskin M. (1993), The emerging party systems of Central and Eastern Europe, „East European Quarterly", XXVII, 1/March.

Rybar M. (2000), Clivages politiques slovaques et perpectives, „Regards sur l'Est”, nr 21, maj-czerwiec.

Rzepkowski K. (1998), Les bases fragiles du „consensus” polonais, „La Nouvelle Alternative”, nr 49 , marzec.

Seiler D.-L. (2001), La comparaison et les partis politiques, Working Papers, núm. 194, Institut de Ciències Polítiques i Socials, Barcelona.

Stadtmüller E. (1998), Polska i kraje Wyszehradu wobec procesów integracji europejskiej, w: Polska i jej sasiedzi w latach 90, wyd. Uniwersytetu Śląskiego, Katowice.

Stachura J. (1992), Partie polityczne a polska polityka zagraniczna, „Rocznik Polskiej Polityki Zagranicznej".

Stefunko I. (2000), La permanence des antagonismes, „Regards sur l'Est”, $\mathrm{nr} 21$, maj-czerwiec.

Stolarczyk M. (1999), Integracja Polski z Unia Europejska - szanse i zagrożenia dla realizacji polskich interesów (podstawowa argumentacja), w: Europa Środkowa jako obszar interesów regionalnych, red. J. Przewłocki, Wyd. Uniwersytetu Śląskiego, Katowice.

Śliwa M. (2001), Czy Polacy wspótcześnie maja myśl polityczna?, w: Europa Środkowa w ostatniej dekadzie XX w. pod red. A. Essena, A. Kastorego, M. Mikołajczyk, Wyd. Akademii Pedagogicznej w Krakowie, Kraków.

Waele de J.-M. (2001), Les grandes familles politiques dans les PECO, „Le courrier des pays de l'Est', nr 1013, marzec.

Wessels B. (2000), Evaluations of the EC: Elite or mass driven?, w: Public Opinion and Internationalized Governance, eds. O. Niedermayer, R. Sinnot, Oxford University Press.

Wojciechowski S., Transformacja ustrojowa w państwach Grupy Wyszehradzkiej-analiza porównawcza, w: Europa Środkowo-Wschodnia a globalizacja, pod red. T. Wallasa, wyd. UAM, Poznań

\section{Streszczenie}

Niniejsza analiza stanowi przegląd pro- i antyeuropejskich postaw w życiu politycznym państw Grupy Wyszehradzkiej w latach 1989-2004. Ich identyfikacja nie była sprawą prosta, gdyż profil środkowoeuropejskich formacji politycznych często zależał od tworzących je osobistości, a programy partyjne, zwłaszcza w pierwszym okresie postkomunizmu, nie nadążały za zmianami w otoczeniu zewnętrznym. W pierwszej połowie dekady, integracja $z$ WE/UE, uznawana była za zagadnienie związane z polityką zagraniczna, co sprzyjało utrzymywaniu się powierzchownego konsensusu w tej kwestii. W miarę wchodzenia w szczegóły negocjacji 
i zbliżania się rozstrzygnięć następowało coraz silniejsze różnicowanie się sceny politycznej na trzy główne orientacje - „pro-europejską", , ,anty-europejską" oraz „,eurosceptyczną" - na tle sporów wokół reform wewnętrznych i ich tempa, warunków członkostwa, stosunków z innymi krajami europejskimi czy docelowego modelu integracji. Zarówno dyskurs pro- jak i anty-europejski opierały się tu do pewnego stopnia na argumentach emocjonalnych, co nie sprzyjało pogłębieniu debaty na tematy związane $\mathrm{z}$ integracją.

Słowa kluczowe: systemy polityczne, partie polityczne, Europa Środkowa, integracja europejska, Grupa Wyszehradzka

\title{
Attitudes of Central European political elites towards integration with the $\mathbf{E U}$ before accession
}

\begin{abstract}
Summary
This analysis reviews pro-European and anti-European attitudes in the political life of Visegrad Group states in 1989-2004. It was not easy to identify these attitudes, as the profile of Central European political parties often depended on the personalities of their most prominent persons and their political platforms, especially during the first period of the post-communist era, and these did not keep pace with the changes that occurred around them. In the first half of the decade, integration with the $\mathrm{EC} / \mathrm{EU}$ was considered an issue related to foreign policy. This was conducive to maintaining a superficial consensus on the matter. As negotiations went into more detail and their finalisation came closer, the political scene became more strongly diversified into three main orientations: ,pro-European”, ,,anti-European” and „Eurosceptic” - based on disputes concerning internal reforms and the pace of these reforms, membership conditions, relations with other European countries or the target integration model. Both pro-European and anti-European discourses were based to a certain extent on emotional arguments, and this did not lead to deeper debates on issues related to integration.
\end{abstract}

Key words: political systems, political parties, Central Europe, European integration, Visegrad Group 
